Journal of Zhejiang University-SCIENCE B (Biomedicine \& Biotechnology)

ISSN 1673-1581 (Print); ISSN 1862-1783 (Online)

www.zju.edu.cn/jzus; www.springerlink.com

E-mail: jzus@zju.edu.cn

\title{
Correspondence:
}

\section{China's postgraduate education practices and its academic impact on publishing: is it proportional?}

Yuan $\mathrm{ZHU}^{\dagger 1}$, Chun-jie ZHANG ${ }^{2}$, Cheng-liang $\mathrm{HU}^{1}$ ( ${ }^{1}$ Graduate School, Zhejiang University, Hangzhou 310027, China) $\left({ }^{2}\right.$ School of Science, Hangzhou Dianzi University, Hangzhou 310018, China)

†E-mail: yuan_zhu@zju.edu.cn

doi:10.1631/jzus.B14a0331

Though postgraduate education started before the founding of new China in 1949, it was not until the implementation of the policy reform and the opening-up in 1978 that China's postgraduate productivity began to take off. Since the introduction of Regulations of the People's Republic of China on Academic Degrees in 1981, the number of graduate students enrolled each year has increased 50 times since 1978. China is now the second largest producer of publications indexed by the database of Science Citation Index (SCI) (Web of Science ${ }^{\mathrm{TM}}$, Thomson Reuters), which reflects great strides being made in the postgraduate education. In this paper, we discuss the relationship between the increasingly high enrollments of graduate students and the quantity (the number) and quality (the academic impact and the originality) of their publications, to see whether there is a correlation.

\section{The ever increasing number of graduate students enrolled each year}

With the development of its postgraduate education, China now has about 1800000 enrolled graduate students. In 2014, there are 630000 new graduate students, including $71000 \mathrm{Ph} . \mathrm{D}$ candidates. Up until 2012, the number of doctorate recipients in

(Di) ORCID: Yuan ZHU, http://orcid.org/0000-0002-6782-7251

CC Zhejiang University and Springer-Verlag Berlin Heidelberg 2014
China rose to about 477000 with an increase of about 70000 Ph.D candidates each year after that. The corresponding number for master degree recipients was about 3211000 with an increase of 500000 master degree candidates each year after that (Fig. 1). Data from the U.S. National Center for Science and Engineering Statistics (NCSES) (2014) also indicated that the increasing rate of Ph.D student numbers in China is far ahead of those in the U.S. and European countries (Fig. 2). China is currently ranked first in the number of graduate student admissions in the world, although the government has controlled the number in the past two years. With the booming increase in the quantity of postgraduate students, the quality of their education, especially the cultivation of their innovative ability, is now listed in many Chinese universities' as one of their top concerns, which is also the focus of China's public interest in higher education.

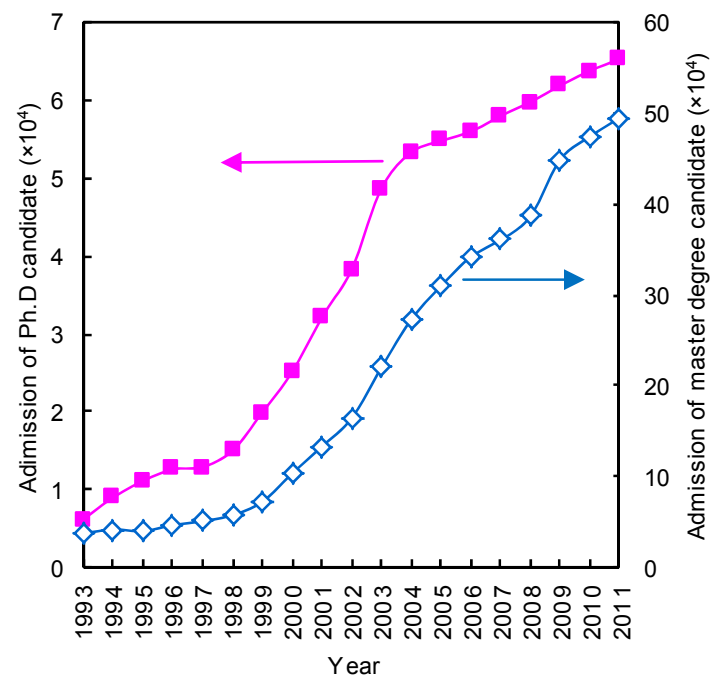

Fig. 1 Number of graduate student admissions each year in China from 1993 to 2011

Data obtained from http://kaoyan.eol.cn/html/ky/baogao/ diaocha1.shtml\#11 (in Chinese) [Accessed on Sept. 21, 2014] 


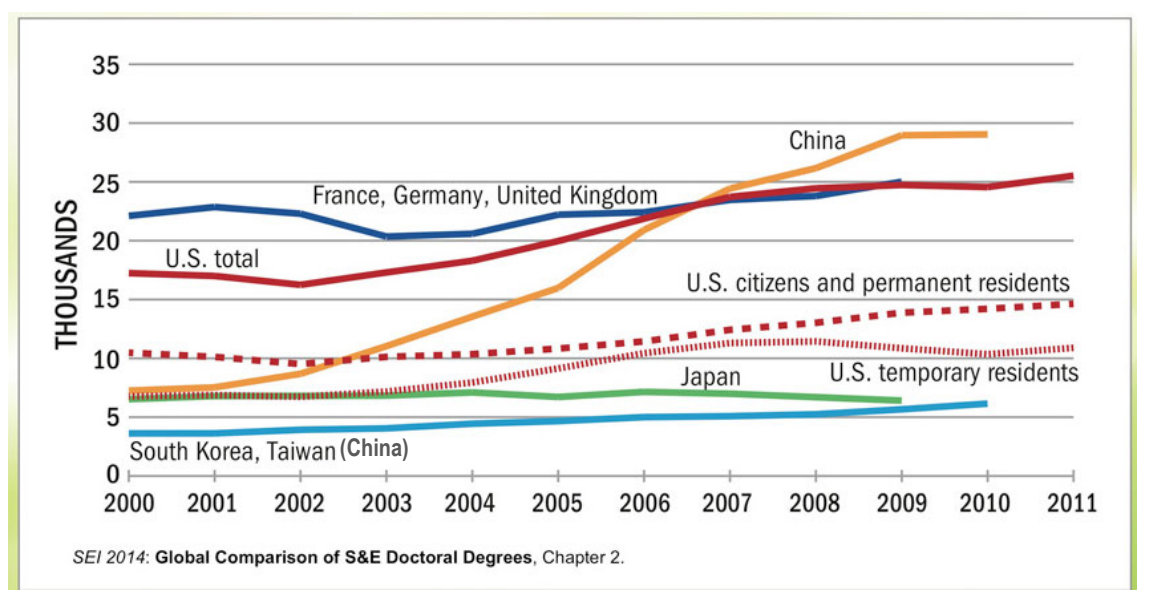

Fig. 2 Doctoral degrees in natural science and engineering by selected country/economy from 2000 to 2011 This figure is modified from NCSES (2014)

\section{Dramatic increase of science publications}

The Institute of Scientific and Technical Information of China (ISTIC) released its Statistical Data of Chinese S\&T Papers 2004-2013 (ISTIC, 2004; 2005; 2006; 2007; 2008; 2010; 2011; 2012; 2013; 2014). Here we focus on the report regarding the indexing of articles from China during the last 10 years, through using two famous databases, the SCI and Social Science Citation Index (SSCI) (Web of Science ${ }^{\mathrm{TM}}$, Thomson Reuters). The report clearly shows the data of the variance of China's contributions to international journals. We explained some of the results in this report as follows.

Table 1 shows the contribution of SCI-indexed articles by Chinese researchers during 2004-2013. We can see that the number has risen to 231400 in 2013, almost four times the number of articles (57400) in 2004, which makes China the second largest country after USA. The percentage of SCI-indexed articles from Chinese researchers has risen from $5.43 \%$ to $13.53 \%$, with an annual increase of $0.9 \%$ which is dramatically higher than the world's average.

Table 2 shows the Chinese researchers' contribution to the SSCI database during the period 2007-2013 (ISTIC, 2007; 2008; 2010; 2011; 2012; $2013 ; 2014)$. Though both the number and its percentage increase steadily each year, the annual number remains less than 10000 and the percentage in 2013 is only about $3.45 \%$. The annual increase is $0.3 \%$, which is relatively low compared to that of the SCI-indexed articles.
Table 1 Data of SCI-indexed articles by Chinese researchers from 2004 to 2013

\begin{tabular}{cccccc}
\hline \multirow{2}{*}{ Year } & \multicolumn{2}{c}{$\begin{array}{c}\text { Total SCI-indexed } \\
\text { article }\end{array}$} & & \multicolumn{2}{c}{$\begin{array}{c}\text { SCI-indexed article } \\
\text { by Chinese author }\end{array}$} \\
\cline { 2 - 3 } \cline { 5 - 6 } & Number & Rank & & Number & Percentage (\%) \\
\hline 2004 & 1056700 & 5 & & 57400 & 5.43 \\
2005 & 1286800 & 5 & & 68200 & 5.30 \\
2006 & 1203400 & 5 & & 71000 & 5.90 \\
2007 & 1267500 & 3 & & 94800 & 7.48 \\
2008 & 1437400 & 4 & & 116700 & 8.12 \\
2009 & 1442300 & 2 & & 127500 & 8.84 \\
2010 & 1421000 & 2 & & 148400 & 10.44 \\
2011 & 1516100 & 2 & & 168100 & 11.09 \\
2012 & 1596700 & 2 & & 190100 & 11.91 \\
2013 & 1709700 & 2 & 231400 & 13.53 \\
\hline
\end{tabular}

Data from ISTIC (2004; 2005; 2006; 2007; 2008; 2010; 2011; $2012 ; 2013 ; 2014)$

Table 2 Data of SSCI-indexed articles by Chinese researchers from 2007 to 2013

\begin{tabular}{cccccc}
\hline \multirow{2}{*}{ Year } & \multicolumn{2}{c}{$\begin{array}{c}\text { Total SSCI-indexed } \\
\text { article }\end{array}$} & & \multicolumn{2}{c}{$\begin{array}{c}\text { SSCI-indexed article } \\
\text { by Chinese author }\end{array}$} \\
\cline { 2 - 3 } \cline { 5 - 6 } & Number & Rank & & Number & Percentage (\%) \\
\hline 2007 & 166600 & 10 & & 2478 & 1.49 \\
2008 & 199100 & 11 & & 3210 & 1.61 \\
2009 & 225200 & 9 & & 5064 & 2.25 \\
2010 & 219700 & 8 & & 5287 & 2.41 \\
2011 & 241800 & 8 & & 6380 & 2.64 \\
2012 & 258800 & 8 & & 8012 & 3.10 \\
2013 & 262800 & 7 & & 9067 & 3.45 \\
\hline Data from ISTIC (2007; 2008;2010;2011;2012; 2013;2014)
\end{tabular}


There are also reports on the Statistical Data of Chinese S\&T Papers 2013 (ISTIC, 2014) regarding the contribution of different types of institutions in China (Fig. 3). Universities and research institutes are two major sources for article publication, which accounts for $95 \%$ of all indexed articles. As a result of the policy adopted by many universities during these years that article publications should be necessary for graduate students to get their degrees, the main contributors of this percentage are graduate students from universities and research institutes. So, it is not surprising that the number of publications has also risen dramatically each year with the booming increase in the number of graduate students.

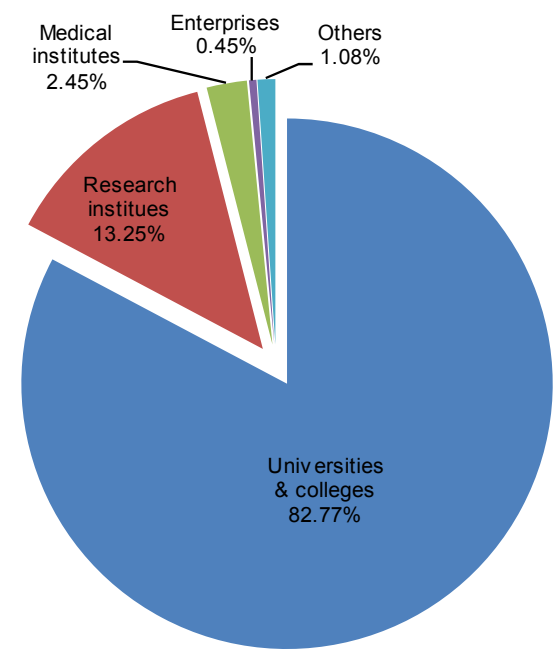

Fig. 3 Distribution of SCI-indexed articles among different types of institutions in China, 2013 (ISTIC, 2014)

\section{Citation data for articles published by Chinese authors}

Since China's graduate students have published a large number of articles in recent years, how about their citation data? It is widely known that citation data can signal the extent of collaboration among researchers, both nationally and across borders. The trend toward more collaboration varies among science and engineering (S\&E) fields, research institutions, and countries. In comparison, the U.S. authors cite articles published by Chinese authors much less than suggested by the overall citation trends. Within Europe and Asia (with the exception of Japan), cross-national citation is common, with most country pairs in each continent surpassing the expected number of citations (National Science Foundation, 2014).

Tables 3 and 4 show two summaries regarding the citation of SCI- and SSCI-indexed articles of China. The total number of SCI-indexed articles for China between 2001 and 2011 ranked second (Table 3). The total number of cites is also rising. However, the rank for average cites per article drops from 12th in 2009 to 15th in 2014. Meanwhile, according to the Statistical Data of Chinese S\&T Papers (ISTIC, 2004; 2005; 2006; 2007; 2008; 2010; 2011; 2012; 2013; 2014), USA has 2.5 times the total SCI-indexed article numbers compared with China, but the average cites per article is 5.5 times higher. The citation of SSCI-indexed articles from China is in a rather awkward situation (Table 4). Very few articles were cited more than 10 times within one year. In some years, the number of such articles was even less than 10 , which represents less than $2 \%$ of all indexed articles. This evidence indicates that our country is lacking in highly cited articles, whether in the area of natural science or social science, given the large number of publications each year.

\section{Originality and academic impact of articles by China's graduate students}

It is the innovative ability of graduate students, rather than their ability to publish more articles, that should be the ultimate goal in postgraduate education. U.S. vice president Joe BIDEN challenged us: "Name me one innovative project, one innovative change, one innovative product that has come out of China." (CNN, 2014). Though this has not become the common thinking among American citizens, Academician Ping-xian WANG from Chinese Academy of Sciences (CAS) proposed three questions based on Vice President Biden's statement. He also encouraged us to meditate on the lack of original contributions in spite of the large amount of articles published, which already makes China the Top 2 producer of SCI articles in the world. We should also reflect on why we have had only one Nobel Prize winner in literature and none in natural science, although submissions, representing the world's largest numbers, are being submitted each year, whereas our neighbor Japan has already had more than 20 Nobel Prize winners since 1949. 
Table 3 SCI citation data of China in each ten-year period

\begin{tabular}{|c|c|c|c|c|c|c|}
\hline \multirow{2}{*}{ Period } & \multicolumn{2}{|c|}{ SCI-indexed article } & \multicolumn{2}{|c|}{ Total cites } & \multicolumn{2}{|c|}{ Average cites per document } \\
\hline & Number & Rank & Time & Rank & Time & Rank \\
\hline 1999-2009 & 649689 & 5 & 3404466 & 9 & 5.24 & 12 \\
\hline $2000-2010$ & 719971 & 4 & 4227779 & 8 & 5.87 & 12 \\
\hline 2001-2011 & 836255 & 2 & 5191358 & 7 & 6.21 & 13 \\
\hline 2002-2012 & 1022597 & 2 & 6653426 & 6 & 6.51 & 14 \\
\hline 2003-2013 & 1142951 & 2 & 7908839 & 5 & 6.92 & 14 \\
\hline 2004-2014 & 1368834 & 2 & 10370132 & 4 & 7.57 & 15 \\
\hline
\end{tabular}

Data from ISTIC $(2008 ; 2010 ; 2011 ; 2012 ; 2013 ; 2014)$

Table 4 SSCI citation data of China from 2007 to 2013

\begin{tabular}{cccc}
\hline Year & $\begin{array}{c}\text { Number of } \\
\text { SSCI-indexed } \\
\text { articles }\end{array}$ & $\begin{array}{c}\text { Percentage with } \\
\text { current year cites } \\
(\%)\end{array}$ & $\begin{array}{c}\text { Number of } \\
\text { more than 10 } \\
\text { cites }\end{array}$ \\
\hline 2007 & 2478 & 25.40 & \\
2008 & 3210 & 21.90 & 3 \\
2009 & 5064 & 13.80 & 3 \\
2010 & 5287 & 11.60 & 3 \\
2011 & 6380 & 37.10 & 11 \\
2012 & 8012 & 20.20 & 5 \\
2013 & 9067 & 30.80 & 18 \\
\hline
\end{tabular}

Data from ISTIC (2007; 2008; 2010; 2011; 2012; 2013; 2014)

We have to conclude that the policy requiring graduate students to publish did have some positive effects which were anticipated through postgraduate education at the very beginning of its establishment in the 1990s, for before turning to the concept of originality; we should at least have a certain number of publications generated by the program. However, the current situation is that, the quality of our postgraduate education cannot keep pace with the ever increasing number of articles being published. On the contrary, the average cites per article are even worse and the contributions which reflect great originality hardly exist. The reason for this trend is that the universities put greater emphasis on the quantity of published articles or patents, rather than their originality. Including some of the top universities and research institutes, almost all are considering the quantity of articles as a key factor in the evaluation of their postgraduate education. The president of Nanjing University, Jun CHEN, an Academician of CAS, recently criticized some academic ranking institutions for adopting the number of published articles as a rating index, as such an index easily stimulates some universities to place greater emphasis on this number. In addition, under such a policy, supervisors are less likely to encourage their graduate students to do more profound research due to the lack of time and the pressure of publishing articles, which ultimately results in poor quality publications.

China is now producing the world's second largest number of SCI articles. So we are in the very position to redirect our policy to encourage more original contributions and to place less emphasis on the number of publications, or to eventually deemphasize this index completely. We are happy to see that such change is now taking place in some of China's top universities when evaluating their graduate students. In considering Zhejiang University for example, we have noticed that in some of its fundamental disciplines, the requirement for publishing is being relaxed as long as the Ph.D candidate's dissertation is approved by the academic board. When the originality of an article increases, so will be its academic influence. And that in turn, will further encourage more original contributions. Then, we will be close to having legitimate Nobel Prize candidates.

\section{Compliance with ethics guidelines}

Yuan ZHU, Chun-jie ZHANG, and Cheng-liang HU declare that they have no conflict of interest.

\section{References}

Cable News Network (CNN), 2014. Joe Biden described China this week as a nation incapable of producing innovative products and ideas. Available from http://money.cnn. com/2014/05/29/technology/innovation/biden-china-inno vation/ [Accessed on Sept. 21, 2014]

Institute of Scientific and Technical Information of China (ISTIC), 2004. Statistical Data of Chinese S\&T Papers 
2004. Beijing, China (in Chinese).

Institute of Scientific and Technical Information of China (ISTIC), 2005. Statistical Data of Chinese S\&T Papers 2005. Beijing, China (in Chinese).

Institute of Scientific and Technical Information of China (ISTIC), 2006. Statistical Data of Chinese S\&T Papers 2006. Beijing, China (in Chinese).

Institute of Scientific and Technical Information of China (ISTIC), 2007. Statistical Data of Chinese S\&T Papers 2007. Beijing, China (in Chinese).

Institute of Scientific and Technical Information of China (ISTIC), 2008. Statistical Data of Chinese S\&T Papers 2008. Beijing, China (in Chinese).

Institute of Scientific and Technical Information of China (ISTIC), 2010. Statistical Data of Chinese S\&T Papers 2009. Beijing, China (in Chinese).

Institute of Scientific and Technical Information of China (ISTIC), 2011. Statistical Data of Chinese S\&T Papers 2010. Beijing, China (in Chinese).
Institute of Scientific and Technical Information of China (ISTIC), 2012. Statistical Data of Chinese S\&T Papers 2011. Beijing, China (in Chinese).

Institute of Scientific and Technical Information of China (ISTIC), 2013. Statistical Data of Chinese S\&T Papers 2012. Beijing, China (in Chinese).

Institute of Scientific and Technical Information of China (ISTIC), 2014. Statistical Data of Chinese S\&T Papers 2013. Beijing, China (in Chinese).

National Center for Science and Engineering Statistics (NCSES), 2014. Science and Engineering Indicators 2014 Digest. Available from http://www.nsf.gov/statistics/ seind14/index.cfm/digest/stem.htm\#4 [Accessed on Sept. 21, 2014]

National Science Foundation, 2014. Science and technology in the world economy. Available from http://www. nsf.gov/statistics/seind14/index.cfm/overview/c0s1.htm [Accessed on Sept. 30, 2014]

\section{中文㯕要:}

本文题目: 中国研究生培养: 论文发表与学术影响力成正比吗?

China's postgraduate education practices and its academic impact on publishing: is it proportional?

主要内容: 中国研究生教育在 1978 年改革开放之后, 规模迅速扩展, 目前已居世界前列。在研究生培养 成果必须以在高端杂志发表论文来体现的政策下, SCI 收录我国发表科研论文的数量也同步 达到了世界第二。虽然 SCI 收录我国发表论文的总被引用次数上升较快, 但是单篇均被引用 次数的上升却稍显缓慢, 从单篇均被引用次数的排名反而呈下降的趋势。由此造成一些国外 学者对我国的学术影响力、创新抱有怀疑态度。因此, 在如此规模的研究生培养状况下, 研 究生论文发表的情况以及与学术影响力、创新等是否成正比是目前急需归纳总结的。改变对 论文数量的追求, 调整为对质量的要求也必定成为当前乃至今后研究生培养政策的调整方向。

关键词组: 中国研究生; 教育; 培养; 论文发表; 学术影响力 